\title{
Mito y realidad o de la realidad antihispánica de ciertos mitos anglosajones*
}

\author{
Juan A. Ortega y Medina
}

IIH-UNAM

A lo largo del artículo, el profesor Ortega y Medina rastrea, desde el siglo XVI, el antihispanismo subyacente en las tesis de diversos pensadores anglosajones.

INTRODUCCIÓN

$\mathrm{E}$

1 mito así como lo mítico no cuentan lo irreal o falso, sino expresan realidades imaginativas que responden a aspiraciones o necesidades colectivas, y galvanizan las energías del hombre hacia la acción común." Se trata de una especie de ideología real operante que ha movido y continúa moviendo los grandes y pequeños acontecimientos históricos; fuerza motora y retardadora, según los casos y circunstancias, puesto que pueden actuar también mitos congeladores y paralizantes. El mito es un elemento justificativo de uso interno y asimismo externo, cuando se trata de convencer a los extraños del ineludible destino que un grupo humano, pueblo o nación ha de cumplir así sea a costa de otros.

Por consiguiente, toda nación está apresada en la tupida red de sus prejuicios históricos, de sus leyendas y, por lo tanto, de sus mitos; empero por lo que se refiere al todavía latente $y$, no obstante, antiguo conflicto material y

* Históricas, núm. 16, enero-abril 1985, pp. 19-42. Publicado con autorización del autor.

${ }^{1}$ Peñuelas, Cultura, 1977, p. 133. 
espiritual-cultural entre el mundo anglosajón (británico y estadunidense) y el hispánico (español e iberoamericano), los recelos, malentendidos y resentimientos mutuos poseen todavía una vigencia estereotipada que impide el franco diálogo comprensivo entre Angloamérica e Hispanoamérica. "El tenaz y amargo conflicto iniciado en el siglo XVI entre el misionerismo español y su contrario, la modernidad inglesa, terminó, como es sabido, con el triunfo absoluto del mundo moderno nórdico, europeo y angloamericano; para expresarlo mejor, como escribe el teólogo norteamericano Paul Tillich, con la entronización definitiva de the protestant era o conquista decisiva del mundo material."

\section{PREDestinación CONDENatoria}

La reforma religiosa del siglo XvI, iniciada por Lutero en 1517, ocasionó el fraccionamiento de la tambaleante cristiandad y coadyuvó al aceleramiento de las tendencias nacionalistas que desde fines del siglo xv venían presionando. El renacimiento europeo, los grandes descubrimientos geográficos, los nuevos mercados, las nuevas invenciones y técnicas ayudarían asimismo a la aparición de un clima de crítica nuevo y de una Europa cristiana fragmentada espiritual y políticamente (reforma-contrarreforma). Una Europa que entre conflictos dolorosos buscaba la renovación mediante la propagación heterodoxa del libre examen, raíz de la doctrina liberal pese al tradicionalismo militante de los grandes reformadores, principalmente Lutero. Mas la historia marchaba irremisiblemente por el nuevo camino: rompimiento con Roma, creación de grandes potencias, absolutismo de Estado, diferente moralidad y secularización de la vida.

De los dos credos protestantes, luteranismo y calvinismo, fue este último el que, si bien a contrapelo, se adaptó mejor a los nuevos tiempos y a las innovaciones, no tanto por obra de Calvino sino de sus seguidores e intérpretes. El nuevo credo ayudó así a la clase histórica emergente, la burguesía, a tomar conciencia de su creciente poder económico-político y a hacer uso del mismo sin los frenos éticos tradicionales (prohibición de la usura) y antiutilitarios del catolicismo medieval.

La doctrina calvinista, ínsita en la famosa Institución cristiana (1558), proporcionó al anglicanismo, establecido por Enrique VIII, una sólida fundamentación teológica y contribuyó además a la a parición del rígido dogmatismo de los puritanos ingleses y escoceses. El protestantismo anglosajón despertó las latentes energías de la incipiente clase burguesa, la cual se enriqueció con la desamortización de la riqueza territorial de la iglesia católica decretada por el Acta de Supremacía (1534) y emprendió la implacable lucha comercial contra el imperio español, logrando en menos de medio siglo arrebatarle el dominio del mar y establecer colonias (Virginia, Nueva Inglaterra e islas caribeñas) en el continente americano monopolizado mercantil y espiritualmente por España. Aquella nueva clase constituida por la nobleza tudoriana de

\footnotetext{
${ }^{2}$ Tillich, Protestant, 1961.
} 


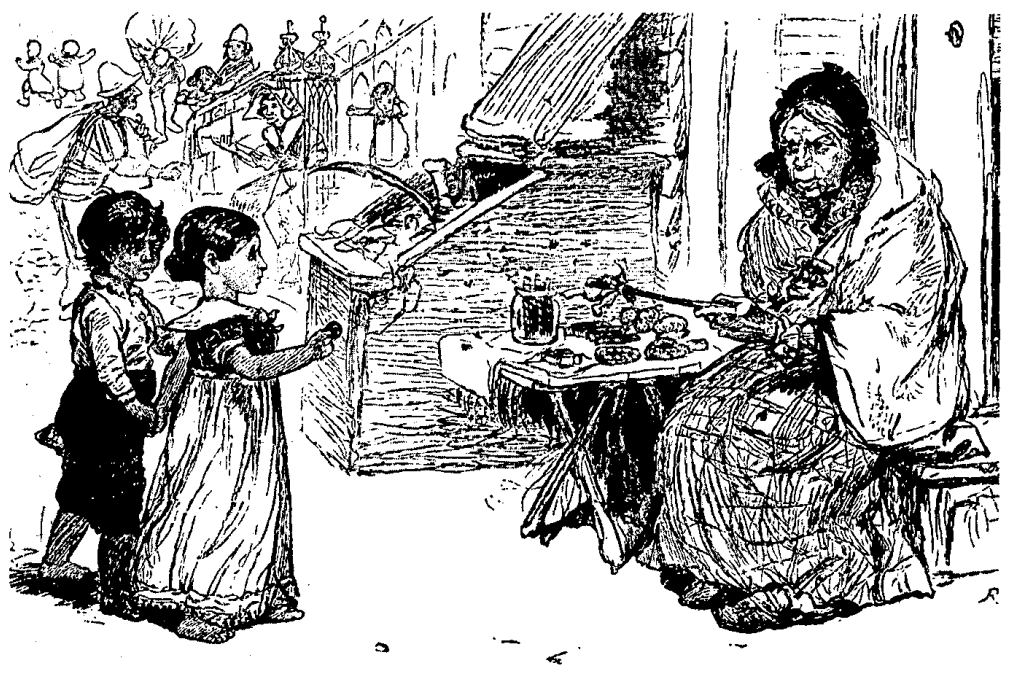

reciente cuño y por comerciantes y hacendados enriquecidos en el río revuelto de la desamortización, transformó a Inglaterra. Los miembros de dicha clase fueron todos hombres endurecidos en los negocios, desembarazados de todo escrúpulo religioso, liberados de toda conciencia social y situados al margen del anticuado sentido feudal de responsabilidad; ${ }^{3}$ eran, en suma, hombres modernos.

La empresa debeladora del protestantismo anglosajón de los siglos XVI y XVII se justificará, por supuesto, mediante razones espirituales, económicas y políticas; había que expulsar a los españoles del continente mal habido; suplantarlos y reconquistar el nuevo mundo por medio de las bondades del evangelio reformado, lo que permitiría además liberar a los indios adoctrinados en el catolicismo de las garras infernales de los papistas y, por consiguiente, de la explotación y de las horribles crueldades, denunciadas, nada menos, por un testigo inobjetable, el obispo Las Casas. En la tierra prometida americana, en la nueva Canaăn de los puritanos, había que combatir denodadamente contra los nuevos filisteos, ya indios o recién llegados. Españoles, franceses e indios contribuían, ayudados por el demonio, a la corrupción, al debilitamiento y a la adulteración de la bondad primigenia del paraíso americano. América, pese a sus dotes naturales, sobrenaturalmente era demoniaca; un continente satánico poblado por los servidores de Luzbel y por los sirvientes desahuciados del Anticristo. La batalla sin cuartel contra tales enemigos era urgente, nece-

${ }^{3}$ Morris, Tudors, 1967, p. 86. 
saria, y la victoria a alcanzar, con la ayuda de Jehová, permitiria extirpar el mal. En el siglo Xxx los estadunidenses se dedicarian con similar y contumaz entusiasmo religioso heredado, a purificar la tierra americana de tan empecatados huéspedes indeseables.

Aunque los colonos de Virginia y territorios adyacentes intentaron cumplir con lo ordenado en las cartas patentes de 1606 y 1609 , de propagar la religión cristiana reformada entre los pieles rojas y convertir y reducir a los naturales al verdadero culto de Dios, una serie de tremendas dificultades económicas y políticas impidió llevar a cabo tan cristiana exigencia. En la Nueva Inglaterra, donde los motivos religiosos predominaron sobre todos los demás, los "padres peregrinos" (1620) y fundamentalmente los "santos" puritanos (1629) emprendieron con fervoroso entusiasmo la predicación evangélica entre los indios y la tarea regeneradora de los mismos. Mas dicha regeneración cristiana resultó un doloroso fracaso: la resistencia estructural del congregacionalismo y el énfasis puesto en la exigencia civilizadora, en tanto que señal de elección, antepuesta al proceso evangelizador, fueron las principales causas del fiasco.

Con la paulatina consolidación de los santos en Massachusetts, al paso que se multiplicaba la población blanca, aumentaban las alianzas contractuales con los indios, y acres sobre acres de tierra cultivable pasaban a los colonos por medio de ventas más o menos legalizadas. Sólo una voz se levantó entonces a favor de los desposeídos y condenó los forzados y marrulleros contratos, la del notable y generoso seeker Roger Williams, quien llegó a comparar a los ambiciosos santos con los execrables españoles, cuya desenfrenada sed de oro era sobrepasada con creces por la inextinguible hambre de tierra de peregrinos $y$ santos. Éstos se defendieron de las críticas de Williams alegando que los indios tenían demasiadas tierras y que no las cultivaban apropiadamente, y continuaron con sus exigencias. Este sistemático despojo provocó la insurrección de los pieles rojas encabezados por el famoso cacique de los wampanoagas, el rey Felipe, y estalló una terrible y desoladora guerra (16751676) en la que los indios quedaron aniquilados y sus tierras pasaron a manos de los vencedores colonos.

La cruel matanza de indios sentó un precedente abominable para el futuro de las relaciones entre los hombres rojos y blancos. Al igual que para los puritanos ingleses y escoceses en la conquista de la Irlanda católica, el mejor irlandés era el irlandés muerto, "el mejor indio" llegó a ser, dos siglos después, según lo expresara el general Sherman, "el indio muerto". El costo moral y religioso fue terrible. A pesar de los celosos y abnegados esfuerzos catequísticos de los Mayhews, Eliot, Gookin, Williams y tantos otros, la empresa falló. El cristiano y filantrópico esfuerzo del traductor de la Biblia al algonquino, John Eliot, para salvar a sus hermanos rojos, ganarlos para el Dios verdadero y hacerles abandonar su diabólica cultura, no obtuvo recompensa; el resultado fue, en primer lugar, la marginación y, después, la destrucción de los aborígenes americanos. En ellos fallaron lamentablemente las rigurosas etapas que todo catecúmeno había de recorrer en su proceso peregrino de redención: vocación, justificación y santificación. Todo esto más la exigencia alfabetizadora para llevar a cabo individualmente el libre examen bíblico, fue para los 
pieles rojas obstáculo insuperable que sólo unos miles de entre ellos pudieron vencer: pequeñas congregaciones de praying indians.

La imposibilidad de asimilación y aculturación cristiana no radicó tanto, no obstante el reiterado y tozudo empeño justificante de los historiadores anglosajones, en el estadio cultural en que se hallaban los pieles rojas (más agricultores y por lo tanto sedentarios, que cazadores y recolectores, conviene advertir), sino en la religión independiente, abstracta y liberadora que se les brindaba, así como en el culto frío y estéticamente nulo de las asambleas puritanas, excelente para hombres reformados, independientes, que cargaban consigo una experiencia religiosa de más de milenio y medio.

Con indios de similar grado de civilización actuaron los jesuitas en el Canadá (hurones y aliados), los españoles en el noroeste de México y en la península de Baja California, o los franciscanos en el actual sudoeste de Estados Unidos; y fueron positivamente recompensados sus sacrificios y desvelos evangelizadores y civilizadores. Luego el fracaso doctrinal regenerador de la empresa evangelizadora puritana dependió no del entusiasmo misionero de los predicadores, sino de la teología calvinista que resultó poco o nada acogedora ni atractiva para seducir a hombres que eran ajenos a las formas de la sociedad europea. Como escribe William C. Clebsch, la condición lastimera del piel roja ilustra el fracaso de la religión y sociedad norteamericanas, herederas de la tradición calvinista, en el intento de llevar a cabo plenamente la mutua participación de los diferentes miembros de las razas en los comunes empeños humanos. ${ }^{4}$ Esto se explica porque el moralismo rígido del creyente puritano exige la señal del éxito (actividad) en el mundo para poder considerarse entre los elegidos; es decir, a salvo. Pero los indios en trance de adoctrinación no reflejaban, a pesar de todos sus esfuerzos, sino pocos o ningún signo positivo de prosperidad intramundana, lo cual ponía evidentemente de manifiesto su irremisible condena predestinatoria.

La religión de los puritanos impidió la transculturación del aborigen y la mezcla de blancos y rojos o miscegenación, como gustan decir los norteamericanos en lugar de mestizaje, no pudo efectuarse por el prurito racista que la teología de Juan Calvino había establecido desde un principio entre los justificados (los menos) y los réprobos (los más). Esto puede ilustrarse si se recuerdan los apuros del llamado "primer embajador angloamericano" ante los indios algonquinos del gran cacique Massasoyt, Edward Winslow, cuando tuvo que pernoctar más de una vez en un wigwan con la turbadora compañía de dos doncellas indígenas destinadas, expresamente a complacerle y a calentar su sueño. ${ }^{5}$ La embarazosa situación del peregrino Winslow no fue precisamente la del novelesco John Smith, poco puritano, por supuesto, asediado por las ninfas indianas, desnudas y danzarinas, y adorado por la famosa Pocahontas,

${ }^{4}$ Clebsch, Sacred, 1967, p. 102.

${ }^{s}$ Willison, Saints, 1964, p. 127. El autor se refiere a la misión de Winslow; pero no dice nada sobre las incomodidades; nosotros las inferimos porque era la costumbre india en todo el continente americano y porque el enviado no lo registra, por pudor puritano, en su diario o relación de su embajada. 
casada después con John Rolfe, liberado, como el capitán famoso, de las represiones sexuales características del protestantismo de Calvino, que había hecho suya la condición expresa del pacto (Abraham-Jacob-lsaac-Moisés), que prohibía el ayuntamiento de los elegidos de Dios con los ateos. A diferencia de lo que acontecía en el mundo hispánico católico, el fértil proceso de mestizaje no pudo ser iniciado, y no por orgullo británico de casta, como sostiene Samuel E. Morrison, ${ }^{6}$ sino por imperativo mandato y temor religiosos. Las ironías del virginiano Robert Beverly, así como los dos Diarios secretos del también sureño y casanovesco coronel William Byrd, además de sus Histories, apuntan contra la discriminación religioso-social que impidió el fecundo proceso de amalgamación racial, ${ }^{8}$ que incluso desde el siglo xv había sido aconsejado por sir Walter Raleigh. ${ }^{9}$

Byrd alababa la práctica francesa en el Canadá, de establecer matrimonios mixtos, y al igual que su cuñado Beverly se inclinaba por la fusión de la sangre y no la efusión de la misma. Estimaba que "un lozano enamorado elral el mejor

${ }^{6}$ Morrison, Builders, 1930, p. 296.

${ }^{7}$ Beverly, History, 1947.

${ }^{8}$ Byrd, Secret, 1941 y Anotber, 1942.

'Las indias guayanesas le parecieron incluso al audaz marino isabelino las más adecuadas, por su hermosura y fortaleza, para regenerar la sangre decadente de la aristocracia inglesa, vid. Hakluyt, Principal, 1919.

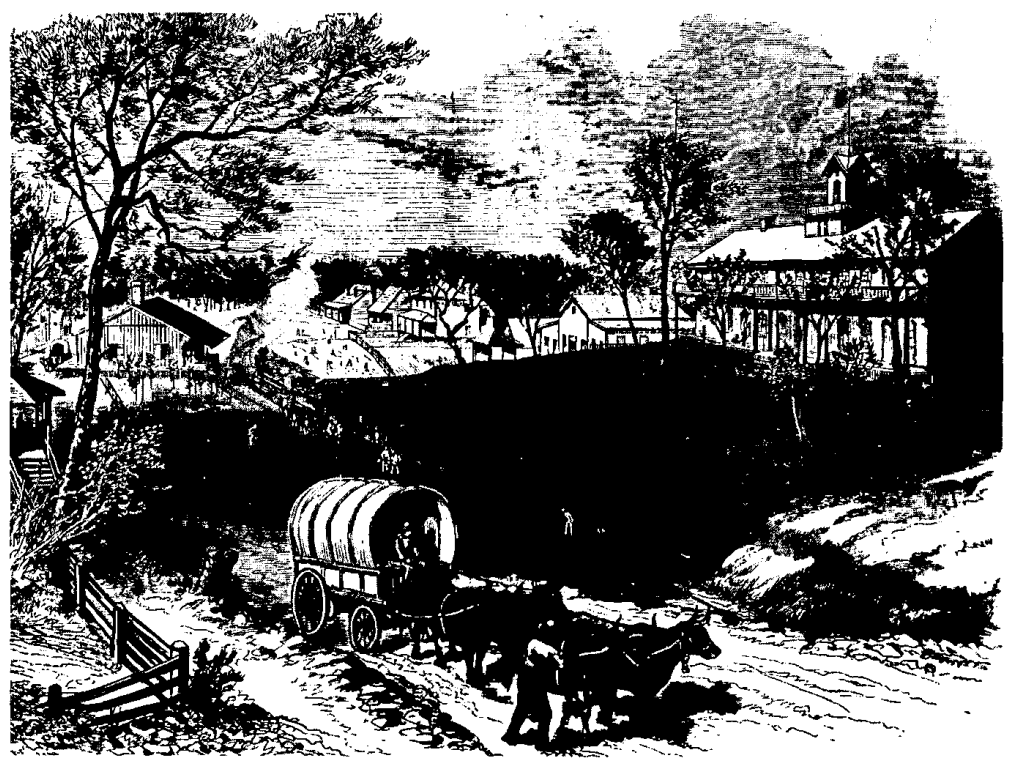


misionero que podía enviarse a estos y a otros infieles" ${ }^{10}$ Por lo que respecta al mundo hispánico, el entrenamiento del mestizaje entre los pueblos que a lo largo de muchos siglos invadieron y se asentaron en la península ibérica, unido al espíritu del catolicismo hispano, que no alentaba pero tampoco impedía la mezcla de españoles e indios, además de negros, permitió la presencia de una nueva raza, la mestiza. La reina Isabel la Católica lo había propiciado y los conquistadores y colonos no tuvieron inconveniente de unirse en matrimonio con las indias, sobre todo con aquellas que podían aportar a la unión bienes y posesiones que, como cacicas o hijas y nietas de prominentes señores, poseían como herencia. El bautizo previo santificante eliminaba el temor español católico a contraer enlaces con súcubos o íncubos.

Los norteamericanos se consideran hasta el día de hoy, salvo honrosas excepciones, los herederos discriminatorios de la ominosa teología social congregacionalista y se sienten orgullosos y darwinianamente predestinados, en tanto que modernos electos, a cargar sobre sus hombros, como escribiera Kipling, el peso progresivo de la civilización: the white man's burden. Hoy como ayer algunos de los hombres más representativos de Estados Unidos se lamentan de tales excesos y perciben que se encuentran viviendo sobre una tierra en la que no están naturalmente enraizados. Como el hombre que perdió su sombra, inquieren la manera de recuperarla, queremos decir que buscan la forma de arraigarse, recurriendo con dramáticos desasosiego y premura a la vía arqueológica e histórica indohispanoamericana en busca de ser, de autenticidad, de apoyo y substancia: monroísmo histórico (Irving, Prescott, Ticknor) y arqueológico (Stephen, Norman y Mayer). ${ }^{11}$

\section{LEYENDA NEGRA}

Como lo han demostrado las obras de Julián Juderías, Rómulo Carbia, Raúl Molina, William S. Maltby, Philip Wayne Powell y otros ${ }^{12}$ la famosa leyenda constituye la fuente de donde proceden todas las campañas de descrédito moral que a partir del siglo Xvi, hasta la fecha, se han desatado contra España e Hispanoamérica, contra sus hombres y su historia.

La raíz y razón de esta officina de execrables mitos se encuentran, sin duda, como es sabido, en el que fue y continúa siendo uno de los monumentos más excelsos del humanismo ibérico y de su profundo sentimiento de justicia, la Brevísima relación de la destrucción de las Indias (Sevilla, 1552) de fray Bartolomé de las Casas, que en manos extranjeras interesadas se convirtió irónicamente en el acta acusatoria más terrible que se haya enarbolado contra una nación. La más poderosa autoacusación (y no fue la única) que jamás ningún pueblo, salvo el español, se haya atrevido a hacer de sí mismo. Contundente arma de combate contra la colonización española en América,

${ }^{10}$ Byrd, Histories, 1929, pp. 3-4.

${ }^{11}$ Ortega y Medina, "Monroísmo", 1953.

${ }^{12}$ Carbia, Historia, 1944; Juderias, Leyenda, 1954; Molina, Misiones, 1955; Maltby, Black, 1971; Powell, Tree, 1971. 
que tuvo el privilegio de 34 ediciones inglesas (desde fines del siglo xv hasta la mitad del xvII), lo que prueba la renovada, combativa y siempre bien manipulada utilización propagandística del opúsculo.

Desde finales del siglo xvi la excerpta viajera de Richard Hakluyt, el joven, ${ }^{13}$ así como la de su continuador Samuel Purchas, no sólo tuvieron por objeto despertar la ambición imitativa, marinera y conquistadora de la Inglaterra isabelina, mediante la inclusión y crítica de las crónicas e historias españolas de Indias, sino también provocar el déscrédito hispano y justificar por ello la necesidad imperiosa de reemplazar a los españoles en el dominio y explotación de América.

Las lágrimas de los mansos indios ${ }^{14}$ (eco de las criticas lascasasianas), que en cataratas de panfletos ingleses y de otras naciones se vierten durante los dos primeros siglos del conflicto angloespañol por el dominio oceánico, y la subsiguiente debelación de las colonias españolas, son lágrimas de cocodrilo que disimulan los voraces apetitos y ambiciones de la nueva clase burguesa capitalista protestante, ya santificada providencialmente.

Uno de los principales portavoces de la leyenda fue el citado Hakluyt, clérigo anglicano, diplomático e historiador, todo en una pieza, quien influyó de modo decisivo en la joven generación inglesa y la orientó e inclinó a la expansión marítima, así como contribuyó eficazmente con sus obras al desprestigio español, atizando por su cuenta, mediante sus discursos y traducciones, la hoguera inextinguible del fabuloso mito de la leyenda negra. Estimulado por la obrita del padre Las Casas, se deleita en repetir todo lo relativo a la matanza de más de veinte millones de indios a manos de los sanguinarios conquistadores. Los españoles no presentan ni siquiera una virtud redentora; constituyen una raza maligna y carnicera, cobarde y traicionera, codiciosa y ladrona; por consiguiente, como escribe un historiador inglés revisionista, "certainly no one but the most skeptical of readers could feel guilty about seizing Spanish lands and property after perusing the Principle voyages, traffiques and discoveries of the english nation" ${ }^{15}$

A nivel popular, la propaganda panfletaria llevaba su venenosa imagen antiespañola al corazón de la masa inglesa. Por ejemplo, en uno de estos panfletos (15891590) se muestra el rencor inglés contra todo lo español y se presenta la bellaqueria de los ibéricos en contraste con la generosidad británica. Esta mongrel generation de españoles es abominable, impíamente ateísta, monstruosa, lujuriosa, cobarde y, sobre todo, inquisitorialmente cruel. ${ }^{16}$

Este caudaloso río de injurias no se interrumpió en el transcurso de los siglos;

${ }^{13}$ Hakluyt, Principal, 1919.

14. Vid., la traducción inglesa de John Phillips de la Brevisima, a cuyo título se antepone este otro: The tears of the indians. Esta versión: "appeared to fortify the righteous indignation of his puritans neighbors", cuando Jamaica era conquistada por las tropas de Cromwell en 1656. Maltby, Black, 1971, p. 13.

is Ibid., p. 71.

${ }^{16} \mathrm{La} \mathrm{selección} \mathrm{del} \mathrm{texto,} \mathrm{reducido} \mathrm{por} \mathrm{nosotros} \mathrm{a} \mathrm{unos} \mathrm{cuantos} \mathrm{infamantes} \mathrm{adjetivos,} \mathrm{en} \mathrm{Powell,}$ Tree, 1971, pp. 75-76. 


\section{SECUENCIA}

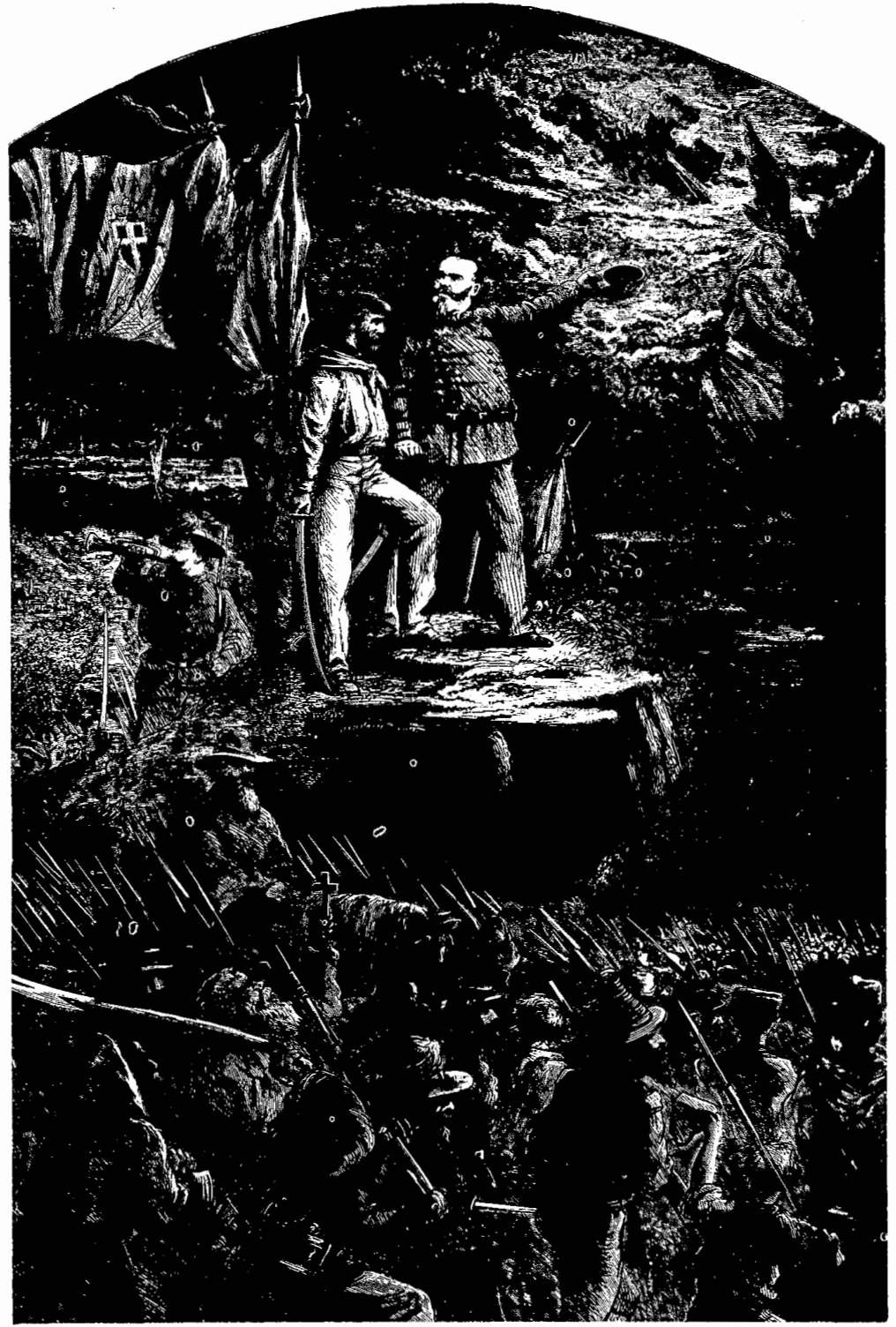


en el XVII, la empresa o western design del dictador Oliverio Cromwell contra el imperio americano de España, fue la resultante de la confabulación de diversos elementos y la suma asimismo de todos los epítetos denigratorios. Cromwell, nutrido históricamente con todas las leyendas infamantes antiespañolas, juzgaba a todos los hispanos de crueles, inmorales y envidiosos. España era además el asiento de la opresión religiosa. El 29 de diciembre de 1654 una poderosa flota inglesa se hizo a la vela en dirección a la Española, cabeza de puente para la ulterior conquista de la Nueva España. La expedición conquistadora, purificadora y, por lo mismo, regeneradora, nutrida con soldados ingleses (ironsides) y reforzada con colonos voluntarios de Barbados, Virginia y Nueva Inglaterra (primera intervención norteamericana, podemos señalar, en Hispanoamérica) fue ideada como una cruzada puritana; pero resultó un desacierto colosal, atenuado tan sólo con la conquista de Jamaica. Cromwell había previamente declarado que sólo le animaba "the glory of God and the advancement of Cbrist's kingdom"; pero de hecho se trataba asimismo, como puede leerse en su Declaración de 1655, de apetitos comerciales, de la seguridad de Inglaterra y de defensa de la religión protestante. En suma, se trataba, como diríamos hoy, de ampliar por medios contundentemente convincentes el ámbito de la libertad. Al año siguiente en la apertura del Parlamento, Cromwell, con todo el furor y despecho acumulados que le proporcionaba su antihispanismo, y con toda la rabia que el fracaso expedicionario le había provocado, masculló un afrentoso discurso contra los españoles, su gobierno y su religión. ${ }^{17}$

Toda esta tremenda propaganda apuntada y descargada puritanamente contra España y los españoles fue anticipando y condicionando las futuras fobias de sus herederos norteamericanos y fue también utilizada y aprovechada por éstos para justificar sus exacciones contra los españoles y mexicanos de aquende y allende el río Bravo.

La crítica despiadada de la Ilustración europea contra el mundo hispánico -fue aceptada irreflexiva y matricidialmente por los criollos ilustrados hispanoamericanos y sirvió de justificado acicate para los esforzados partidarios de la independencia. Ellos tomaron al pie de la letra los juicios críticos o, mucho mejor, prejuicios, de los enemigos del Imperio y los aceptaron en bloque para constituir con ellos el venero de donde brotarían todos los reproches con los que juzgarían no ya únicamente la obra político-económica tricenturial de España en América, sino incluso el espíritu de su cultura, de su raza, de su historia e inclusive de su lengua, sin caer en la cuenta que al actuar así ponían temerariamente en peligro los valores más entrañables de su propio ser histórico. Arrojaban piedrạs sobre su propio tejado y quedaban desarmados frente a la penetración cultural y económica de los ambiciosos intereses extranjeros.

La admiración por Inglaterra y mucho más por Estados Unidos se convirtió en ocasiones en apasionamiento desmedido. A raíz de la independencia de Hispanoamérica la euforia liberal hizo clausurar y renunciar, tan entusiasta

\footnotetext{
${ }^{17}$ Cromwell, "Speech", 1971, pp. 56-57.
} 
cuanto impremeditadamente, a los criollos a su inmediato pasado (los siglos de historia colonial conformativa), por considerar con excesiva ingenuidad que éste les había simplemente pasado y no, como de hecho ocurrió, constituido. Las nuevas y recién nacidas naciones hispanoamericanas, al cortar dramáticamente sus lazos con un pasado juzgado absolutamente negativo, se ofrecían a sí mismas, ante la mirada de los extranjeros, acrisoladas, virginales, antiespañolas y románticamente indigenistas. Se pensó y se creyó que los de fuera sólo verían aquella pura naturaleza moral y política con la que se surgía al mundo moderno tras la destructora y cruenta guerra civil. Aspiraban a que se las viera como querían ser vistas; es decir, a las mejores luces del presente y sin los claroscuros del ayer entorpecedor. Al romper violentamente con España se quiso también que ella sola apurara el cáliz de su famosa leyenda negra y que ni la menor sombra de ésta empañara el cándido esplendor de nuestras nobles matronas republicanas. Empero los otros, los de siempre, los que habían batallado denodada y tozudamente a lo largo de tres centurias contra todos los valores hispánicos, penetraron o rasgaron con sus inveterados prejuicios y estereotipos históricos las vestes solemnes y pudorosas y descubrieron o vieron bajo ellas la misma vitanda criatura hispánica, incluso todavía más degenerada, contra la que habían luchado y a la que habían desacreditado a partir del siglo XVI. La indolencia, la crueldad, la anarquía, el fanatismo e inclusive la cobardía española siguieron siendo los tópicos vigentes para caracterizar ahora a los descendientes de la espuria España.

De nada sirvieron las mejores intenciones y protestas. Buena parte de la literatura viajera sobre Hispanoamérica, así como la populachera o amarillista (the dime novels) trasluce, si no es que continúa trasluciendo, el antiguo desprecio y la vieja incomprensión coheredadas. La situación resultó trágica: a la buena fe se opuso la malicia; a las rectas intenciones, los engaños. Fue un pesado tributo el que se tuvo que pagar a causa del lastre hispánico, porque los otros se empeñaron en ignorar la ingenua actitud de querer ser distintos y continuaron viendo al criollo y mestizo a través de los lentes ahumados de sus rancias monomanías antiespañolas.

La revolución de independencia, con su rechazo a España, creó en la conciencia criolla, hay que repetirlo, la necesidad de sustituir el pasado colonial, su pasado, por un neoaztequismo o un neoincaísmo, u otros neos, suplantadores del viejo orden. Fue abolido el pasado colonial y dogmático, y un indianismo entusiasta y reivindicador, arqueológico e histórico, de corte romántico y sentimental, además de deshispanizante, intentó desplazar a la herencia cultural histórica española.

Actualmente estas efervescencias nacionalistas, por lo que toca a México, ya no inquietan, aunque con el menor pretexto aparece el trasgo de la polémica entre los llamados indigenistas e hispanistas cuyos respectivos símbolos son Cuauhtémoc y Cortés, y en el Perú, Atahualpa y Pizarro. Al parecer el indohispano no ha digerido todavía su mestiza historia; aún sigue cargándola, como lo subraya clara y desacomplejadamente la historiadora Beatriz Ruiz Gaytán de San Vicente, "como si fuera un vergonzante sambenito, únicamente porque una triste fábula ennegrece los andares de algunos antepasados, 
porque nos frena en la total responsabilidad de ser lo que somos: americanos de raíz india e hispánica" ${ }^{18}$

Esto debe valer también para nuestros hermanos que viven en el sudoeste de Estados Unidos, que bajo distintos nombres (mexicano-americanos, hispanos, hispánicos, chicanos, etc.) defienden su lengua castellana, sus costumbres, su folclore; empero su vehemente y justificado indigenismo idealizado en Aztlán, como lo muestra en parte su literatura, a cuenta de su commitment to the indian side of their beritage ${ }^{19}$ debiera ampliarse mediante un hispanismo histórico-cultural que lo completase y enriqueciese, supuesto que constituye la otra mitad de su entidad mestiza, hasta ahora menospreciada y escamoteada por los intereses económicos, políticos y culturales de los anglos. El debilitamiento de los hispánicos significa, al parecer, la aceptación del complejo de inferioridad provocado en buena parte por la leyenda negra manipulada por los anglosajones desde el siglo XVI. La mejor muestra de la liberación y progreso del indoespañol que vive en Estados Unidos será, sin duda, su mayor contribución al enriquecimiento cultural del mundo hispánico y será asimismo la mejor prueba de su emancipación cultural.

\section{IMITACIÓN: DEMOCRACIA AL SESGO}

A Edmundo O'Gorman se debe la aguda distinción ontológica que establece entre Angloamérica e Hispanoamérica, en cuanto toca a los origenes respectivos. La primera adopta el modelo europeo anglosajón a sus propias circunstancias y da paso así al ejercicio de la libertad religiosa, política y económica; la segunda imita al dechado y hace suyos los valores del mundo católico hispanoeuropeo. Angloamérica liberará al hombre occidental americano de sentirse subordinado a un europeocentrismo universal; Hispanoamérica liberará al hombre de Occidente de un cerrado concepto del mundo ${ }^{20}$ De aquí habrán de surgir discrepancias, interpretaciones y vivencias históricas distintas y aun opuestas; pero también, al menos por parte de los hombres iberoamericanos, el afán imitativo del modelo anglosajón americano, en virtud del éxito progresista de "éste, si comparado con el retroceso y congelamiento del mundo hispánico. Se imita y copia la Constitución americana (1777) que queda así convertida en panacea para el futuro éxito político de México. Se creyó que bien aplicada nuestra Constitución futura (1824) aportaría a México el progreso y la felicidad espiritual y material ínsitos en ésta. No se prestó atención a la advertencia de Montesquieu, sobre la dificultad de aplicar fórmulas políticas ajenas al espiritu general de la nación.

Nuestros hombres públicos de comienzos del siglo xix no comprendieron que la Constitución americana unificaba libertades y principios espirituales y políticos compartidos por todas las colonias británicas en América. Cuando

\footnotetext{
${ }^{18}$ Ruiz Gaytán, "Vigencia", 1972, p. 25.

${ }^{19}$ Robinson, Mexico, 1977, p. 353.

${ }^{20}$ O'Gorman, Invención, 1958, pp. 79-99.
} 


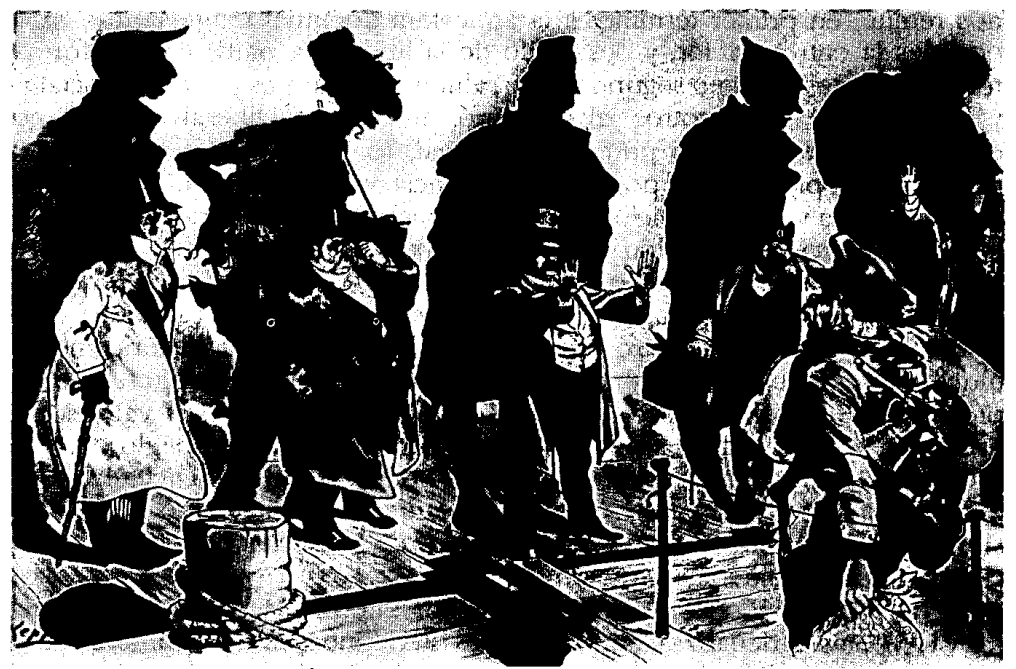

Jefferson dio forma a la Declaración de Independencia, las ideas contenidas en ella no fueron primordialmente suyas: derivaban de convicciones, ideas, creencias y prácticas que se hallaban muy extendidas y cultivadas en las Trece Colonias, y se habían originado en las minorías religiosas desprendidas del calvinismo puritano: congregacionalista, anabaptista, presbiteriana, cuáquera, morava, etc., que dieron lugar o paso, a la larga, a la democracia política.

A veces nos hemos preguntado si cuando recurrimos al vocabulario político (libertad, liberalismo, conservadurismo, democracia, reacción, federalismo, republicanismo, etc.) aludimos con él a lo que aluden los historiadores y politólogos norteamericanos cuando los emplean. Para ilustrar el punto analizaremos, dentro de esta serie conceptual enunciada, el vocablo segundo: liberalismo. Como se sabe, el término adquirió su valimiento oral y su confirmación escrita en las Cortes de Cádiz (1812); pero en cuanto a su contenido de valores espirituales, económicos y políticos, únicamente englobaba y modernizaba toda una serie de elementos dispersos, gracias a la firme acuñación del neologismo político. Es evidente que cuando empleamos dicha palabra en un contexto histórico determinado, estamos expresando con ella una categoría semántica igual o muy próxima a la que utilizaría un estudioso estadunidense al incluir en su narración el vocablo liberalism. Pero es indudable que en el escritor anglosajón el término poseería una resonancia, un eco histórico tradicional que no se correspondería, en manera alguna, con la resonancia evocadora del nuestro. En su acepción anglosajona el liberalismo 
nos remite, en primer término, a la atmósfera doctrinal religiosa que hizo posibles la entronización y desarrollo de la libertad a partir de la reforma religiosa protestante; en segundo lugar, alude a los valores políticos, sociales y económicos. En nosotros, al contrario, el concepto liberal, aunque no desconoce el significado primario espiritual, lo considera no tanto como peregrinante proceso en pos de la tolerancia y libertad espirituales, sino como decidida y terca oposición victoriosa, conseguida a contrapelo de nuestra intimidad, de nuestra tradición histórica y espiritual. El liberalismo anglosajón se desarrolla y se alcanza desde o a partir de la tradición religiosa protestante; el nuestro se desenvuelve y logra desenraizándose de la tradición católica.

Esto significa que nuestro liberalismo hispánico resulta históricamente mucho más contradictorio y patético que el anglosajón. Éste, antes de su proceso de total secularización y antes también, de asumir sus valores no estrictamente espirituales, se inició con la disidencia religiosa del siglo XVI, que proclamaba la libertad espiritual del nuevo hombre cristiano. Dicha libertad espiritual de los reformadores condujo paulatinamente a la democracia eclesiástico-política fomentada por los dirigentes de las sectas protestantes más combativas y revolucionarias.

El famoso sermón del ministro del Señor Thomas Hocker, en Hartford (31V1638), las Ordenanzas Fundamentales de Connecticut ("la primera constitución escrita de la democracia moderna", según V. L. Parrington) y los principios religioso-políticos sustentados por Roger Williams (Providencia) y William (Pennsylvania), marcan, entre otros muchos, el progresivo proceso de la tolerancia religiosa $y$, en consecuencia, de la democracia: contribuciones esenciales para la futura configuración de Estados Unidos. Asimismo, el intenso y emocional movimiento religioso de comienzos del siglo XVIII, conocido como "El gran despertar", nueva y popularísima religión del corazón, que hacía extensiva a todo el pueblo norteamericano la santidad de elección, o elección indiscriminada para toda la mayoría (la mayor felicidad para el mayor número), así como la oposición del eclesiástico John Wise (Massachusetts, 1717) a las pretensiones absolutistas del gobernador de la corona, Andros, establecerían las bases de la futura democracia jeffersoniana. Más aún, la proliferación de denominaciones religiosas, todas ellas caracterizadas por sus tendencias democráticas, influyó en los movimientos filantrópicos, misionales, educacionales, antialcohólicos, pacifistas y antiesclavistas posteriores.

Sin que desdeñemos las aportaciones de las ideas políticas y de la filosofía ilustrada inglesa (Locke), y francesa (Montesquieu), del racionalismo humanista e incluso del deísmo, la primitiva democracia estadunidense revela en sus instituciones no sólo las influencias de la nueva filosofía, sino la presencia sobre todo de las viejas raíces religiosas.

Entre los patriotas norteamericanos creadores de la nación, no fue habitual el hacer gala de escepticismo religioso y mucho menos el presumir de ateos: $\mathrm{Ni}$ aun los cuáqueros, tan liberales en materia de creencias, toleraban el ateísmo. El famoso y desafiante Dios no existe de nuestro radical Ignacio Ramírez, El Nigromante, no tiene réplica por parte de las cabezas representativas 
norteamericanas. Abraham Lincoln, quien no fue precisamente miembro de ninguna iglesia, pero que durante toda su vida asistió a una presbiteriana, en su siempre recordada Oración de Gettysburg apeló a sus compatriotas para que estuvieran siempre "resueltos a demostrar, que su nación, amparada por el Todopoderoso, haría renacer la libertad". Lincoln sabía muy bien que hablaba para un pueblo religiosamente democrático o, si se quiere, democráticamente religioso. Por donde quiera, en grabados, escudos, monedas e himnos (el de Katherine Lee Bates, por ejemplo), se encuentran encendidas si no es que férvidas invocaciones al Dios protector de la nación; al Dios que la favoreció en sus empresas: Annuit coeptis, como reza en el gran sello nacional.

Nuestros liberales puros del siglo pasado, así como los menos acrisolados de nuestro tiempo, a diferencia de los políticos estadunidenses, de suyo enraizados en la tradición inglesa, tuvieron que emanciparse de la suya española. J. V. Lastarria definió el republicanismo norteamericano como un desarrollo natural surgido de un seno común; Francisco Bilbao vio en el catolicismo el obstáculo que impedía afianzar en Iberoamérica la libertad, y vio asimismo en él la raíz de todos nuestros males políticos. Nuestro doctor en teología José María Luis. Mora, cuya ideología liberal ha llevado a más de un investigador a convertirlo en protestante, no podría haber hecho suya la base espiritual heterodoxa del liberalismo sin un desgarramiento intensamente dramático. Para Mora, como para la mayor parte de nuestros liberales de antaño, la concepción irrestricta de la libertad de conciencia, para sí mismo y para el pueblo, estaba más allá de todas sus posibilidades psíquicas e históricas. Esto implica que el liberalismo que ellos profesaban carecía del basamento religioso que hizo posible entre los estadunidenses la secularización de sus creencias e ideas sin violentos desequilibrios sociales, sin graves desgarres anímicos y $\sin$ rompimientos durante las primeras etapas de la consolidación nacional.

El interés exclusiva y egoístamente individualista de la doctrina liberal mexicana de la segunda mitad del siglo Xxx, tiene por antecedente lo que ha sido llamado el áspero individualismo norteamericano, violador frecuentísimo de los añejos ideales cristianos mediante una brutal explotación de los débiles, de los pobres y de los indios; mas nuestro liberalismo, aunque también fue despiadado con los campesinos, jornaleros, y cruel, sobre todo con los indios, paternalizó y humanizó las relaciones socioeconómicas, no se olvidó del todo de la caridad cristiana y rechazó el darwinismo social norteamericano, de procedencia protestante, con todas sus consecuencias desmoralizadoras.

En suma: si en el Acta de Filadelfia pudieron proclamar los norteamericanos la libertad de conciencia, es porque de hecho ya la tenían, histórica y religiosamente, en tanto que descendientes de antepasados espiritualmente libres. Paso a paso los estadunidenses procedieron a la secularización política de los ideales religiosos sustentantes. Desde siempre les fue habitual el expresarse mediante un caracteristico lenguaje político, religioso-liberal, revelador en sí mismo de una convivencia social sin estridencias y sin fracturas, salvo frente al mundo indio. Nosotros, de modo diferente, tuvimos que aprender a ser liberales porque nunca lo habíamos sido. Tuvimos que romper con denuedo y angustia 
con un pasado que, en cuanto tal, vivía donde únicamente le es posible vivir, en nuestro presente histórico; lo cual significó y todavía significa un vivir desviviéndose, un desasosiego constante, una permanente revolución del espíritu.

Mediante ímprobos ensayos y esfuerzos casi hemos logrado aclimatar a la madre democracia y a su liberal hijo bajo nuestra latitud histórica; pero las dificultades pasadas y presentes se manifiestan al desnudo cuando observamos las crisis (seamos piadosos en la sustantivación) que sacudieron ayer y sacuden aún hoy a nuestras iberoamericanas repúblicas y, por supuesto, a España. Adoptamos unos principios políticos sin habernos protestantizado lo suficiente como para hacerlos viables. Nuestras reincidencias patemalistas nos están diciendo claramente sobre qué inseguro tremedal se asientan nuestras precarias y oscilantes democracias. Todo el siglo pasado y buena parte del transcurrido hasta hoy, nos los hemos pasado discutiendo y combatiendo amargamente; nuestras luchas políticas testimonian nuestro desequilibrio psíquico y, por ende, el político, el económico y el social. El precio que se ha pagado y que se continúa pagando ha sido muy alto; pero no fue ni es sino el necesario para confeccionarnos un traje liberal a nuestra exacta medida: ja nuestra sartorial elegancia política!

La resultante de esta casi imitación constitucional extralógica, la tenemos en el hecho de que en México, incluso hoy, nuestra Carta Magna de 1917 y los códigos que de ella emanan no presentan la congruencia innegable que por contra existe entre la vida política y jurídica norteamericana y entre la ley escrita y su aplicación práctica.

En México -escribe Lorenzo Meyer- la situación es bastante diferente.

En realidad, nosotros hemos vivido desde hace tiempo con dos constituciones: una escrita, a la que se le hacen homenajes pero no se obedece, y otra no escrita, a la que se critica en nombre de la primera, pero a la que es muy difícil y peligroso ignorar. Ambas constituciones se mantienen en un estado de guerra constante. La primera está inspirada en las constituciones liberales, democráticas y republicanas de Estados Unidos y Francia, entre otras. La otra proviene de nuestra vieja práctica paternalista y autoritaria. Cuando los principios de ambas entran en conflicto-lo que es frecuente- es la Constitución escrita la que sale perdiendo. Esto lo sabemos casi todos, de ahí el alto grado de obediencia por los principios no escritos, cuyas raíces son posiblemente prehispánicas pero sin duda coloniales. Los ejemplos, desafortunadamente abundan ¿quién de entre nosotros no sabe que la Constitución de 1917 establece la división de poderes a la Montesquieu?, pero ¿quién ignora que la Constitución real ordena la concentración de todo el poder en manos del presidente?21

No tiene, por consiguiente, nada de extraño, que ante tantos fracasos, fallas y desilusiones los mexicanos hayan asumido un complejo de inferioridad ante el éxito arrollador, en todos los campos, del modelo estadunidense, y que por el contrario hayan adquirido éstos, por las mismas pero inversas razones, el arrogante de superioridad frente a los mexicanos. Empero no estará por demás

\footnotetext{
${ }^{21}$ Lorenzo Meyer, "Las dos ...", Excélsior, 27 de diciembre de 1984.
} 
recordar y añadir lo que hace ya tiempo declaró Salvador de Madariaga: el mito de superioridad nórdico se debe en no pequeña parte al hecho de que los mapas se cuelgan con el norte arriba y el sur abajo.

\section{DESTINO MANIFIESTO}

El historiador norteamericano Frederick Merk establece una perspicaz distinción entre la teoría y la práctica del llamado destino manifiesto y la idea de misión, en tanto que forjadora de la expansión territorial y política, respectivamente, de Estados Unidos. ${ }^{22} \mathrm{El}$ espíritu nacional se expresa más auténticamente (Franklin, Paine, Adams, Hay, Jefferson, etc.) por medio del espíritu de misión (o tarea a realizar) y representa las ideas de la mayor parte de los mejores norteamericanos hasta el presente: idealismo, esperanza del favor divino para las aspiraciones nacionales, autoabnegación e insistencia, siempre renovada, sobre los valores de la civilización norteamericana. Dentro de esta mística nacional el espíritu de misión se opone al destino manifiesto y al imperialismo, que son, según el autor que analizamos, ideas de una minoría egoísta y agresiva que postula la superioridad indiscutible e innata de la raza anglosajona y del credo protestante, asi comola supremacía de la forma republicana y democrática de la organización política, aunada a la aneja creencia de que el futuro,

${ }^{22}$ Merk, Manifest, 1963.

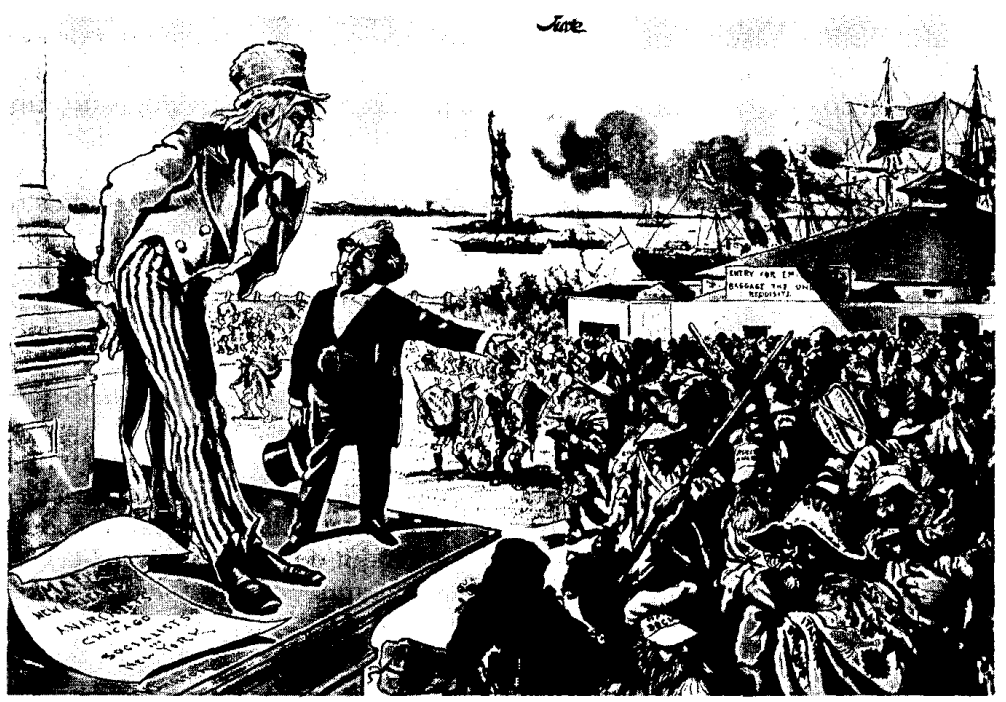


incluso el predestinado, podría ser apresurado por medio de la entusiasta actividad humana, la cual no necesitaría ser justificada si el objetivo a alcanzar fuera considerado bueno por los que lo estaban planeando como meta.

El destino manifiesto no tiene, pues, nada que ver, según Merk, con los progresos religiosos del proselitismo y de la regeneración, con la filantropía, con los propósitos del bien común y con la riqueza pública, ni con los planes económicos a beneficio de las clases populares. Además, el destino manifiesto difiere de la misión en que ésta es perdurable, permanece aún viva; en tanto que aquél se ha desvanecido en el siglo presente. El autor no deja de reconocer que, aunque incompatibles ambos (destino y misión), se han presentado más de una vez mezclados, si bien no por lo que concierne a las actividades depredadoras y agresivas de $1840-1848$ y $1890-1898$. Para nosotros, la dicotomía, la división, de acuerdo con Merk, resulta ingenua, pero no convincente ni, por tanto, operativa. No podemos seguir al autor en su buena fe de creer que el famoso Plan Marshall, pongamos por caso, o la intervención armada norteamericana contemporánea en Asia o en Iberoamérica hayan obedecido exclusivamente al espíritu de misión: salvaguarda de la libertad política e individual, igualdad de derechos ante la ley, oportunidades económicas para todos y equidad de todas las razas y credos religiosos. Incluso, podemos añadir por nuestra cuenta, para matizar todavía más la doctrina estadunidense de misión, el respeto por la forma de gobierno elegido libremente por el pueblo y la no intervención en los problemas políticos de las naciones consideradas bajo su tutela. Depositaria de todos estos indiscutibles ideales es la misión, palabra y contenido semánticos considerados por el propio Merk; pero la misión, en su sentido cristiano profundo, tradicional y puritano, implica un impulso desinteresado y amoroso y, por consiguiente, no coercitivo, porque hablar de misión punitiva, y ha habido demasiadas por parte de los norteamericanos en los tiempos modernos, resultaría un evidente paralogismo; un contrasentido no sólo filológico sino asimismo y fundamentalmente religioso. De hecho y como casi siempre ha sucedido, la misión ha dado paso y propiciado inclusive la acción arbitraria, contundente y agresiva del manifiesto destino como ultima ratio o medio persuasivo eficaz de realización, alli donde el evangelio misional es rechazado o no es suficientemente acatado y atendido. El ejemplo más significativo sería, sin duda alguna, el que nos presenta el activo misionero Teodoro Roosevelt, el as del garrote, no tan distante del calvinismo como suponía William A. White, puesto que el "muscular cristianismo" del agresivo presidente, a base de estacazo y tente tieso, termina justamente lo que empezó con el calvinismo ${ }^{23}$ Hay mucho en el popular Teddy de franklinismo y darwinismo social; también existe en él, como en muchos otros norteamericanos representativos de su tiempo o cercanos a éste, el cristiano empeño de salvar al hombre y al mundo incluso de sí mismos, abatiendo o arrollando todos los obstáculos que se oponen al programa salvador de regeneración. Mas, si bien se mira, este programa no deja de ser sino aquel mismo forjado por el

${ }^{23}$ Cit. Jones, Extraño, 1966, p. 173. 
puritanismo y que no obstante su camuflaje secularizante resulta reconocible en sus más conspicuos portavoces: Whitman (el poético), O'Sullivan (el profético), Emerson, J. Fiske y J. W. Burgnes (los filosóficos pragmáticos) y J. Strong, darwinista social por más señas (el eclesiástico). Y esto sin contar con el ya citado primer Roosevelt ni con otros no menos voceros y realizadores prácticos del destino manifiesto como A. Jackson y J. M. Polk. Según el reverendo ministro Josiah Strong, las razas inferiores prepararon el camino del Señor a fin de que las costras muertas de los credos fósiles (católico, mahometano, judio, budista, brahmanista, etc.) fuesen arrancados para establecer el credo verdadero, es decir, el de los anglosajones reformados: una fe más pura y un linaje humano más fino de acuerdo con el plan de Dios. ${ }^{24} \mathrm{El}$ punto de vista de Strong no difiere en el fondo del que los puritanos novoingleses del siglo XVII se habian trazado para clarear las tierras americanas de árboles, fieras, indios y papistas.

La misión adquiere así una actitud hostil y combativa, que sin dificultad podemos calificar de cruzada: operaciones de castigo que en el pasado ejecutaron con manifiesta ferocidad, según se apuntó, los peregrinos y santos puritanos contra los indios rebeldes que rechazaban o renunciaban a la cristianización, o al trato con los blancos; y expediciones de conquista, ayer, y punitivas y regeneradoras, inclusive hoy, contra los pueblos y naciones desordenados, desviados, revoltosos y anárquicos, que se resisten a aceptar el nuevo secularizado evangelio de la civilización norteamericana, de la democracia y libertad estadunidenses, según la entienden y practican los nuevos campeones y depositarios del progreso: del puritan-american way of life. En suma, Merk ha intentado disfrazar, so capa de espiritualidad, los egoísmos y agresiones múltiples de la doctrina del destino manifiesto o, para decirlo con expresión y contenido modernos, de defender los intereses norteamericanos, ya logrados o por lograr, en no importa que parte del mundo.

Como escribe Weinberg, ${ }^{25}$ refiriéndose a la traslación tipológica de la ideacreencia de pueblo elegido, desde su contextura bíblica a la político-económica estadunidense, la antropocéntrica teología de éstos llegó a extremos peligrosos al modificar el dogma tradicional de que el hombre existe ad majorem gloriam Dei, porla herejía moderna de que Dios existe ad majorem gloriam bominis. Para Weinberg es bien claro que muchos de los fundamentos doctrinales de la teoría del destino manifiesto, por ejemplo el derecho a la tierra incultivada o mal cultivada, lo cual significaba no obtener de ella el rendimiento debido, supuesto atribuido a los pieles rojas y a los mexicanos allende el Bravo, se deriva de los puritanos norteamericanos (novoingleses), los cuales estaban bíblicamente seguros de la intención de Dios respecto a este punto.

En 1830 los indios cheroquis ya civilizados, cristianizados y participantes entusiastas del sistema de vida americano, fueron obligados a dejar sus tierras y poblados y a cruzar el Mississippi ante la violenta presión de los colonos y aventureros blancos; es decir, los hombres más groseros que uno pueda

${ }^{24}$ Cit. Merk, Manifest.

${ }^{25}$ Weinberg, Manifest, 1935. 
imaginarse y como jamás se haya visto, los cuales constituían una masa humana prodigiosa y corrompida como nunca antes se había congregado en cualquier parte del mundo. ${ }^{26}$ Las autoridades de Georgia, por un lado y, por el otro, la actitud incalificable del presidente Jackson conspiraron de consuno en el criminal proyecto de expulsar a los indios, sin tomar para nada en cuenta la resolución justiciera a favor de éstos por parte de la Corte Suprema de Justicia (J. Marshall). El argumento del gobernador de Georgia, George M. Troup fue que, en efecto, la posesión de la tierra se legitimaba mediante el cultivo de la misma (cosa que efectivamente realizaban extensiva e intensivamente los indios cheroquis, poniendo en ello gran esfuerzo y celo), pero que en este caso la Providencia divina había decretado que los cultivadores no debían ser labradores rojos cristianizados, sino colonos blancos protestantes.$^{27} \mathrm{En}$ el caso de los mexicanos, desposeídos en Texas, Nuevo México y California, el argumento cohonestante para justificar el despojo fue también de corte tradicional: que los mexicanos, se arguyó, no obtenían de sus tierras el debido rendimiento. En los archivos poscoloniales a menudo el investigador se tropieza con argumentos de semejante jaez. Como silogizaba con desparpajo Samuel Houston, cazador de hombres, si los norteamericanos habían engañado siempre a los indios y si los mexicanos, según él, no eran mejores que los pieles rojas, no veía la razón por la cual no seguir con aquéllos el mismo procedimiento para quitarles sus tierras. ${ }^{28}$

A lo largo de tres centurias de deshonor, y no sólo una como supuso con justa indignación la señora Helen Hunt Jackson, el procedimiento para apoderarse de tierras ajenas por compra (?), asimilación o guerras injustas no varió mucho.

La herencia puritana de los norteamericanos se muestra patente, por ejemplo, en este hecho: sin haber probablemente leído el senador georgiano Benton lo escrito por el ministro John Winthrop, de la Bahía de Massachusetts, quien justificaba las fundaciones de los colonos en la Nueva Inglaterra respaldándolas con el argumento bíblico (Génesis 1,28), sus conclusiones coinciden con las del gobernador novoinglés en lo relativo al cultivo de la tierra. Los colonos americanos al igual que sus antepasados, los puritanos ingleses y novoingleses del siglo xvıı cumplian, ellos sí, los designios del Creador. Jacob -como argüirá asimismo en el Congreso el representante de Georgia, Wilde-obtendrá siempre la herencia de Esaú. No podemos alterar los designios de la Providencia cuando los vemos impresos en la experiencia de siglos. ${ }^{29}$ Para Winthrop se trataba de ejercer el derecho de ocupación de la tierra por parte de los electos del Señor (santos yperegrinos); para Benton el derecho pertenecía sin disputa a una "raza superior", supermánica podríamos decir, ante la cual tendrían que ceder, tarde o temprano, como el repudiado Esaú, las razas inferiores, las poco evolucionadas y por lo tanto rechazadas pese a sus

\footnotetext{
${ }^{26}$ Brandon, American, 1961, p. 262.

${ }^{27}$ Cit. Weinberg, Manifest, 1935, p. 87.

${ }^{28}$ Ibid., p. 90.

${ }^{29}$ Cir. Weinberg, Manifest, 1935, p. 85.
} 
primigenios derechos americanos; es decir, indios, españoles y mexicanos. El decreto divino discriminatorio (predestinación negativa) subsiste, pero mechado ya de un anticipado darwinismo social, que llegaría a campear en Norteamérica entre 1847 y 1899 .

La teoría, según Weinberg, de que el cultivo del suelo estaba ordenado por Dios y constituía una causa de moralidad, ha figurado a lo largo de toda la historia de las relaciones con los indios y mexicanos, y también ha estado presente en todos los casos er que los norteamericanos han codiciado la tierra ocupada por una raza inferior.$^{30}$ Éstas fueron, entre otras, las razones alegadas para arrebatar a México las tres cuartas partes del territorio nácional.

En el informe de la asamblea democrática del estado de Nueva York (1848), a nombre del beneficio de la humanidad se consideró la necesidad de apropiarse de todo México. No deseamos, se dice, quedárnoslo para uso exclusivo nuestro, sino para el de todos los hombres. El trabajo fue el medio consagrado a éstos, cuando fueron creados, para subvenir a sus necesidades. Henchir la tierra y sojuzgarla fue la misión ordenada al hombre y fue asimismo su destino. ${ }^{31}$ De acuerdo con esto los ingleses primeramente y los norteamericanos después fueron movidos en sus depredaciones por el mismo o casi mismo impulso religioso y codicioso. La moraleja final redimitoria consistirá, portanto, en justificar desde el punto de vista del destino manifiesto el all America de los británicos en los siglos XVI al XvilI y el all Mexico purificante de los estadunidenses de 1847 en adelante. Por fortuna el tropicalismo degenerador ${ }^{32}$ y el racismo de procedencia puritana nos libraron de la absorción total.

El legado puritano proyectado en destino manifiesto se convirtió en misión (regeneradora), democrática, libertaria y republicana sobre todo el continente americano y sobre el mundo entero. Se aspira a una escala universal bajo el lema de extensión del área de la libertad, que no deja de ser sino la secularización de la vieja tesis espiritual de la regeneración salvadora.

Los filósofos, amén de políticos y pensadores, norteamericanos, los Jefferson, J. Adams, Franklin y Monroe, para qué citar otros, creyeron con añorante y militante fe de puritanos que a Estados Unidos competía la misión providencial de preservar, perfeccionar y fortalecer la libertad, la democracia y la aplicación de la doctrina de los derechos naturales a las tareas concretas de gobierno.

Según Justin Smith, notable historiador parcialista en su historia de la guerra de 1847, la inspiración moral de los expansionistas se derivó de la concepción de un deber religioso capaz de regenerar al pueblo infortunado del país

${ }^{30}$ Ibid., p. 73.

${ }^{31}$ Ibid, p. 83.

${ }^{32} \mathrm{El}$ historiador inglés George Trevelyan se felicita de los fracasos americanos de la gran generación marina isabelina: "De este modo se forjaba un futuro más grande para la colonización anglosajona, que si [ellos] se hubieran aprovechado de la oportunidad ofrecida por la guerra (1588) de anexionarse las colonias tropicales de España y Portugal, dirigiendo con ello la corriente de la emigración inglesa hacia esos climas profundamente desmoralizadores." Las cursivas son nuestras. Historia, 1943, p. 247. 
enemigo, atrayéndolo hacia el santuario de la democracia norteamericana. ${ }^{33}$ De modo parecido pensó el director del Daily Union de Washington al incluir un comentario de un pensilvanés, quien opinaba que la realización religiosa de la gloriosa misión nacional, bajo la guía de la protección divina, era un hecho. La panacea de la regeneración prendió en todos. El 11 de febrero de 1848 el senador Reverdy Johnson se mostraba disgustado por las numerosas doctrinas metafísicas y credos extraños que pululaban por doquier y expresaba que Estados Unidos había sido designado misionero por obra del cielo para llevar la luz de la civilización a ese ignorante país, México, incluso por medio del fuego, de la espada y del degüello. ${ }^{34}$

En suma, el destino y misión manifiestos (teología nacionalista) se configuran programáticamente con el anglicanismo (siglo xvI); se refuerzan y organizan durante la etapa colonial espiritualmente puritana (sigloxvil); se proyectan en términos filosóficos ilustrados hasta culminar con la independencia (siglo XVIII) y se secularizan y liberalizan políticamente en el siglo xIX y en lo que ya va recorrido del xx. De hecho todos los temas filosófico-políticos del liberalismo tienen su punto de partida enla gran revolución religiosa del sigloxv, aunque algunos de ellos a veces parezcan, si mirados o experimentados superficialmente, haber crecido a redropelo.

El derecho a la seguridad que fue defendido contundentemente por Inglaterra frente al imperio español, fue también una doctrina heredada por Estados Unidos, y hasta tal punto la llevaron a sus últimas consecuencias que, como le rearguyó nuestro secretario de Relaciones, Crescencio Rejón, a Wilson Shanon, jefe de la misión americana, "la intranquilidad de la nación norteamericana por su seguridad la llevaría a la asimilación de todo el continente americano" ${ }^{35}$

Por último, vale la pena referirse a la acuñación de la frase manifest destiny y al momento de su aparición gráfica. La expresión llegó a convertirse en un reclamo el año de 1846 durante el acalorado debate sobre los límites de Oregón (fifty for forty or fight), cuando Robert Winthrop, de Massachusetts, se acordó de la alusión famosa de Francisco I, según cuenta Jovio, y manifestó en la Casa de Representantes que él se uniría a los abogados del destino manifiesto el día que éstos le mostraran la cláusula en el testamento de Adán, merced a la cual se les otorgase el legado que les autorizara a gobernar el hemisferio occidental. La frase había corrido previamente de boca en boca como consigna a ras de mocasín, es decir, a nivel populachero; empero su mayor rango intelectual y programático lo había alcanzado desde que un tesonero periodista, John J. O'Sullivan, en la edición de julioagosto de la Democratic Review (1845) la consagró en un artículo referente a Texas, en el que defendía y justificaba en nombre del Manifest Destiny la desmembración sufrida por México (Texas).

Weinberg y sobre todo Merk distinguen entre misión y destino e imperialismo, y sin duda les asisten algunas buenas razones históricas para hacerlo así.

\footnotetext{
${ }^{33}$ Smith, War, 1919, t. Il, p. 243.

${ }^{34}$ Cit. Weinberg, Manifest, 1935, p. 175.

${ }^{35}$ Cit. Ortega y Medina, Destino, 1972, p. 142.
} 
Nosotros no es que las desdeñemos, pero nos resultan inoperantes por dos razones: la primera, porque nos hemos remontado en el origen de la doctrina a sus fuentes primarias puritanas, anglosajonas, y las tres etapas las vemos como las adecuaciones sucesivas de las tesis a la realidad histórica cambiante; la segunda, porque considerada la doctrina desde el punto de vista mexicano, particularmente las últimas etapas, no encontramos diferencias, supuesto que tuvimos que experimentar en carne propia y a costa de inmensos territorios perdidos, o de intervenciones y expediciones militares más o menos recientes, el peso aplastante del destino manifiesto de nuestros muy buenos amigos.

\section{BIBLIOGRAFÍA}

-Beverly, Robert, The bistory and present state of Virginia, Louis B. Wright, Chapel Hill, 1947.

-Brandon, W., The american beritage book of Indians, Dell Publishing Co. Inc., Nueva York, 1961. 1942.

-Byrd, William, Another secret diary of W. Byrd of Westover, 1739-1741, Richmond, Raleigh, 1929.

,Histories of the dividing line between Virginia and North Carolina, The secret diary of W. Byrd of Westover, 1709-1712, Richmond, Ed. The

Dietz Press, 1941.

-Carbia, R. D., Historia de la leyenda negra bispanoamericana, Consejo de la Hispanidad, Madrid, 1944.

-Clebsch, William C., From sacred to profane America, Nueva York, 1967.

-Cromwell, Oliver, "Speech at the opening of parliament, 1656", Charles Gibson, The

black legend, anti-spanish attitudes in the old world and the new, Alfred A. Knopf, Nueva York, 1971.

-Hakluyt, Richard, The principal navegations, 8 vols., J. M. Dent and Sons, Londres, 1919.

-Jones, Howard Mumford, Este extraño nuevo mundo, traducción de Andrés M. Mateo, UTEHA, México, 1966.

-Juderías, J., La leyenda negra. Estudios acerca de la España en el extranjero, Editora Nacional, Madrid, 1954.

-Maltby, W. S., The black legend in England, Duke University, Durham, N.C., 1971. -Merk, Frederick, Manifest Destiny and mission in american bistory, Vintage Books, Nueva York, 1963.

-Molina, Raül Alejandro, Misiones argentinas en los arcbivos de México, Instituto Panamericano de Geografía e Historia, México, 1955.

-Morris, Christopher, The Tudors, Fontana Librery, Londres, 1967.

-Morrison, Samuel E., Builders of the bay colony, Houghton Riverside Press, BostonNueva York, 1930.

-O'Gorman, Edmundo, La invención de América, FCE, México, 1958. 49).

-Ortega y Medina, Juan Antonio, Destino Manifiesto, SEP, México, 1972 (Sepsetentas,

"Monroísmo arqueológico. Un intento de compensación de americanidad insuficiente", Cuadernos Americanos, núms. 5-6, 1953. 


\section{SECUENCIA}

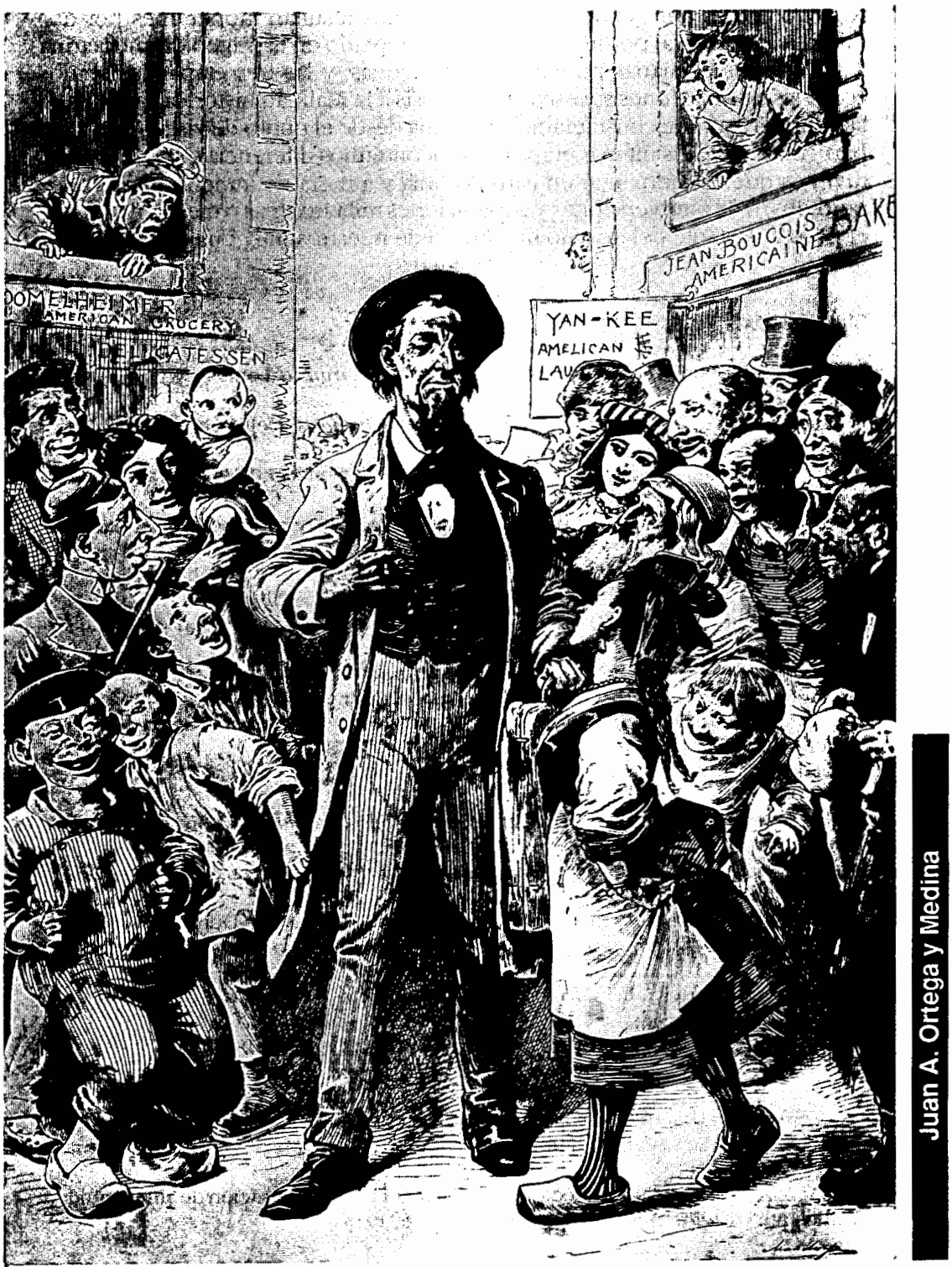


-Peñuelas, Marcelino G., Cultura bispánica en los Estados Unidos. Los chicanos, Ediciones de Cultura Hispánica, Madrid, 1977.

-Powell, P. W., The tree of hate, Basic Books, Inc. Publishers, Nueva York-Londres, 1971.

-Robinson, Cecil, Mexico and the bispanic soutbwest in american literature, The University of Arizona Press, Tucson, 1977.

- Ruiz Gaytán, Beatriz, "La vigencia de la leyenda negra como factor de retraso en Hispanoamérica", Quaderni Iberoamericani, núm. 41, 1972.

-Smith, Justin, The war with Mexico, The MacMillan Company, Nueva York, 1919.

-Tillich, Paul, The protestant era, Chicago, 1961.

-Trevelyan, George, Historia política de Inglaterra, traducción de Ramón Iglesia, FCE, México, 1943.

-Weinberg, Albert K., Manifest Destiny, The John Hopkins Press, Boston, 1935.

-Willison, G. F., Saints and strangers, Time Reading Program Special Edition, Nueva York, 1964. 


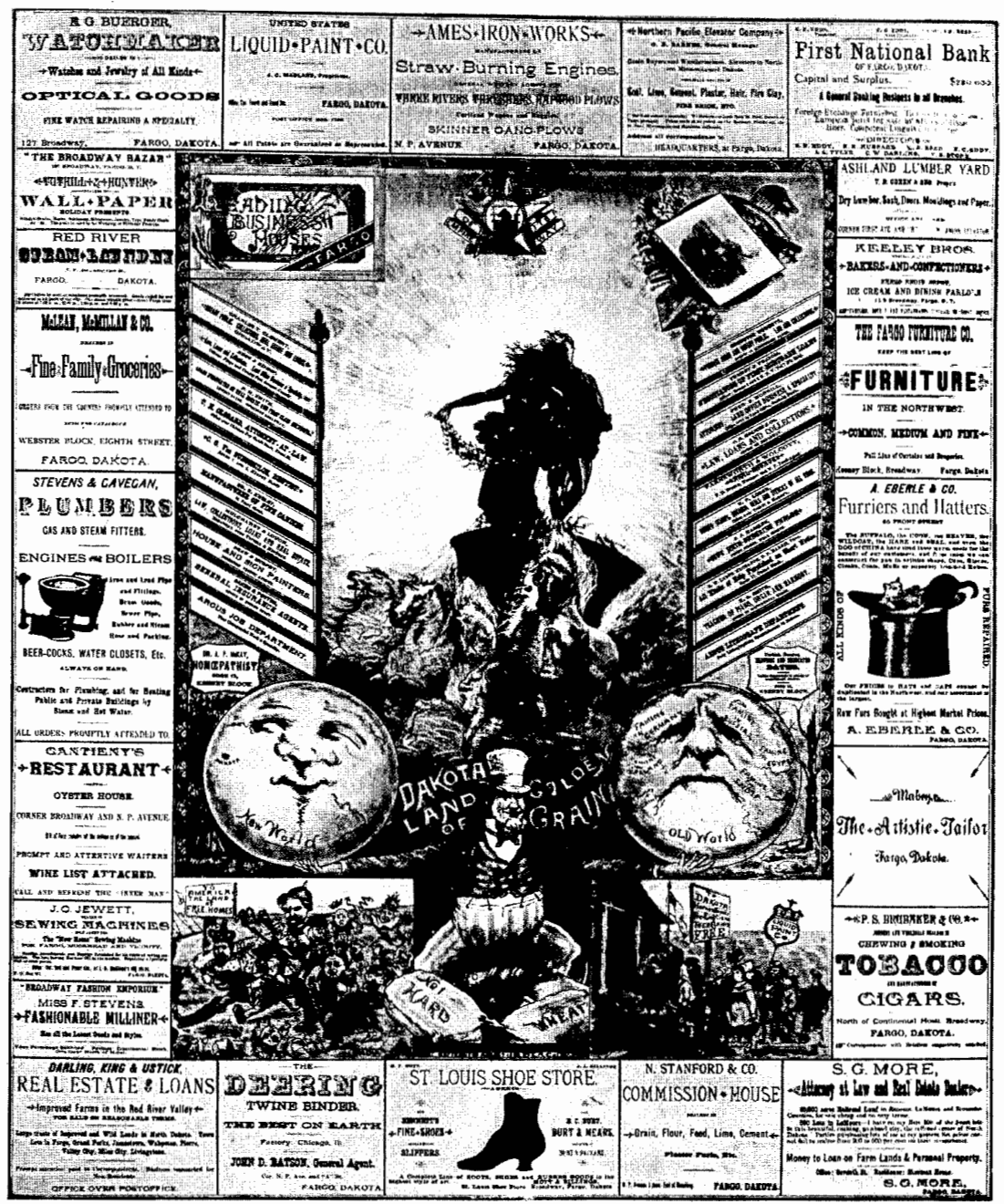

